\title{
MANAJEMEN PESERTA DIDIK
}

\section{Jaja Jahari}

Universitas Islam Negeri Sunan Gunung Djati Bandung JI. A.H. Nasution No. 105 Cibiru Bandung

Email: jajajahari@uinsgd.ac.id

\section{Heri Khoiruddin}

Universitas Islam Negeri Sunan Gunung Djati Bandung JI. A.H. Nasution No. 105 Cibiru Bandung

Email: herikhoiruddin@uinsgd.ac.id

\section{Hany Nurjanah}

Universitas Islam Negeri Sunan Gunung Djati Bandung JI. A.H. Nasution No. 105 Cibiru Bandung

Email: hany2503@yahoo.co.id

\section{ABSTRAK}

Manajemen peserta didik bisa menjadi wadah untuk meningkatkan kualitas dan prestasi pada madrasah. Peserta didik dikelola dengan baik dan benar supaya dapat di ukur keberhasilannya prestasi peserta didik pada lembaga pendidikan.Manajemen peserta didik merupakan usaha pengaturan terhadap peserta didik mulai dari peserta didik tersebut masuk sekolah sampai dengan lulus sekolah, adapun kegiatan dari manajemen peserta didik adalah perencanaan, pembinaan, evaluasi dan mutasi. Tujuan penelitian ini adalah mengetahui manajemen peserta didik di Madrasah Tsanawiyah Al-Mursyid Kota Bandung. Metode penelitian adalah metode penelitian kualitatif dengan pendekatan dalam melakukan penelitian yang berorientasi pada fenomena. Data yang diperoleh berupa data dari hasil observasi, wawancara, dan studi dokumentasi. Hasil dari penelitian diperoleh simpulan bahwa Madrasah Tsanawiyah Al-Mursyid Kota Bandung didirikan selama 25 tahun menciptakan peserta didik yang unggul dengan konsep manajemen peserta didik di Madrasah Tsanawiyah al-Mursyid melalui kegiatan perencanaan peserta didik, pembinaan peserta didik, evaluasi peserta didik, dan mutasi.

Kata Kunci: Manajemen, Peserta Didik, Madrasah

\section{ABSTRACT}

Management of students can be a place to improve the quality and achievement of madrasas. Students are managed properly and correctly so that they can be measured the success of student achievement in educational institutions. Student management is an effort to regulate students starting from 
those students entering school until graduating from school, while the activities of student management are planning, coaching, evaluation and mutation. The purpose of this study was to determine the management of students in the AlMursyid Islamic Primary School in Bandung. The research method is a qualitative research method with an approach to conducting phenomenonoriented research. Data obtained in the form of data from the results of observations, interviews, and study documentation. The results of the study obtained conclusions that the Al-Mursyid Islamic School of Madrasah Tsanawiyah in Bandung was established for 25 years creating superior students with the concept of management of students in Madrasah Tsanawiyah alMursyid through student planning activities, fostering students, evaluating students, and mutation.

Keywords: Management, Students, Madrasah

\section{PENDAHULUAN}

Manajemen peserta didik merupakan penggabungan dari kata manajemen dan peserta didik. Manajemen adalah suatu proses yang khas terdiri atas tindakan-tindakan berupa perencanaan, pengorganisasian, penggerakan, dan pengendalian yang dilaksanakan untuk menentukan serta mencapai sasaran atau tujuan yang telah ditentukan melalui pemanfaatan sumber daya manusia dan sumber-sumber lainnya. Sedangkan peserta didik adalah sebagai suatu komponen masukan dalam sistem pendidikan, yang selanjutnya di proses dalam proses pendidikan, sehingga manusia yang berkualitas sesuai dengan tujuan pendidikan nasional. Adapun fungsi manajemen peserta didik menurut Suwardi dan Daryanto (2017: 99) adalah sebagai wahana bagi peserta didik untuk mengembangkan diri seoptimal mungkin, baik yang berkenaan dengan segi-segi individualitasnya, segi sosial, aspirasi, kebutuhan dan segi potensi peserta didik lainnya.

Berdasarkan wawancara dengan pihak kepala sekolah Madrasah Tsanawiyah Al-Mursyid Kota Bandung, diperoleh gambaran bahwa MTS AlMursyid tersebut merupakan salah satu jenjang pendidikan islam formal yang berada di bawah suatu Yayasan, yang dimana sekolah ini di bawah naungan Kantor Wilayah (Kanwil), Kementrian Agama (Kemenag) provinsi Jawa Barat dan Pemerintahan Kota Bandung. Dimana sekolah ini merupakan sekolah yang lebih mengutamakan kepada nilai pendidikan agama Islam (PAI) yang menjadi salah satu kriteria untuk pengrekrutan peserta didik dalam bidang akademiknya.

Dalam kegiatan ini hal yang menjadi ketertarikan penulis mengenai perencanaan peserta didik adalah berkurangnya jumlah peserta didik yang mendaftar dengan peserta didik yang masuk pada hari pertama pembelajaran, dari yang pertama mendaftar berjumlah 25 peserta didik dan yang datang menjadi 15 peserta didik. Selain itu dalam proses pembinaan peserta didik dimana pembinaan peserta didik ini lebih menguatkan kepada ekstrakulikuler peserta didik untuk mengembangkan minat dan bakatnya, yang lebih 
mengunggulkan kepada dua ekskul yaitu padus dan pramuka, padahal beberapa anak mempunyai minat dan bakat yang berbeda dari dua ekskul tersebut, sehingga tidak bisa diasah minat dan bakat peserta didik. Selanjutnya dalam tahap evaluasi peserta didik, pihak sekolah selalu mengevaluasi dari tahap perencanaan tetapi ada saja permasalahan yang timbul dalam setiap peserta didik. Dan yang terakhir adalah mutasi peserta didik hampir $50 \%$ siswa yang pindah karena beberapa faktor yang menyebabkan siswa tersebut harus pindah, salah satunya yaitu masalah pembinaan peserta didik yang mengakibatkan peserta didik pindah kesekolah lain karena pembinaannya yang kurang efektif dan efesien. Hal tersebut berdasarkan studi pendahuluan yang dilaksanakan di Madrasah Tsanawiyah Al-Mursyid Kota Bandung pada tanggal 12 Desember 2017 pukul 15.30 WIB oleh pihak kepala sekolah.

\section{KAJIAN TEORI}

Manajemen sebagai suatu proses perencanaan, pengorganisasian, dan penggunaan sumber daya organisasi lainnya agar mencapai tujuan organisasi yang telah ditetapkan (Badrudin, 2013:2-4). Peserta didik adalah orang yang memiliki potensi dasar yang pernah dikembangkan melalui pendidikan, baik secara fisik maupun spikis, baik pendidikan itu di lingkungan keluarga, sekolah, maupun di lingkungan masyarakat dimana anak tersebut berada (Dini Oktara, Jurnal Administrasi Pendidikan, Vol. 1 No. 1 Oktober 2013, hlm. 329). Jadi manajemen peserta didik menurut Jaja Jahari (2013:17) dapat diartikan sebagai layanan yang memusatkan perhatian pada pengaturan, pengawasan, dan layanan individual seperti pengembangan keseluruhan kemampuan, minat, kebutuhan sampai matang mendapatkan proses pendidikan di sekolah.

Tujuan manajemen peserta didik adalah mengatur kegiatan-kegiatan peserta didik agar kegiatan-kegiatan tersebut menunjang proses pembelajaran di lembaga pendidikan (sekolah); lebih lanjut, proses pembelajaran di lembaga tersebut sekolah dapat berjalan; lancar, tertib dan teratur sehingga dapat memberikan kontribusi bagi pencapaian tujuan sekolah dan tujuan pendidikan secara keseluruhan (Tim Dosen UPI, 2017:206).

Fungsi manajemen peserta didik (Suwardi dan Daryanto, 2017:99) adalah sebagai wahana bagi peserta didik untuk mengembangkan diri seoptimal mungkin, baik yang berkenaan dengan segi-segi individualitasnya, segi social, aspirasi, kebutuhan, dan segi-segi potensi peserta didik lainnya.

Semua perencanaan yang disebutkan dalam hasil penelitian pada dasarnya telah sesuai dengan prosedur yang seharusnya oleh pihak sekolah terutama kepala sekolah selaku manajer pendidikan di sekolah. Dengan mengedepankan kegiatan yang inovatif, sekolah ini menyusun perencanaan manajemen kesiswaan sesuai dengan perkembangan dan kebutuhan sekolah. Senada dengan yang diungkapkan dalam hasil penelitian bahwa, proses perencanaan merupakan langkah awal yang harus dilakukan sebelum 
diselenggarakannya proses rekrutmen siswa baru (Ria Sita Ariska, Jurnal Manajer Pendidikan, Volume 9, Nomor 6, November 2015, hlm. 832). Adapun langkah-langkah perencanaan terhadap peserta didik menurut Suwandi dan Daryanto (2017:110-113), yang meliputi kegiatan analisis kebutuhan peserta didik, rekrutmen peserta didik, seleksi peserta didik, orientasi peserta didik baru, penempatan peserta didik (pembagian kelas), dan pencatatan dan pelaporan peserta didik.

Manajemen peserta didik terdapat sub aspek penting setelah peserta didik masuk dalam lingkungan pendidikan terutama dalam sekolah. Prosoes pembinaan, disiplin peserata didik, yaitu proses pembinaan pada peserta didik agar mereka dapat melakukan proses pendidikan secara maksimal. Penddikan memang jalur utama yang harus ditempuh untuk ikut dalam perkembangan zaman. Pendidikan merupakan sarana untuk membekali generasi baru dengan pengetahuan dan keterampilan yang dibituhkan untuk dapat bertahan dalam kelompok masyarakat (Gathut dan Desi, Jurnal Inspirasi Manajemen Pendidikan, Vol. 4 No. 4 April 2014). Pembinaan peserta didik adalah membina peserta didik sehingga berkembang kemampuannya secara maksimal sesuai dengan tujuan sekolah. Pembinaan peserta didik dilakukan sehingga anak mendapat bermacam-macam pengalaman belajar untuk bekal kehidupannya di masa depan. Oleh sebab itu, sangat penting bagi sekolah untuk membina mereka agar mereka mudah menyesuaikan diri dengan lingkungan tempat belajar mereka sehingga diharapkan dapat menciptakan suatu keadaan dimana peserta didik dapat lebih tertib dan lebih mementingkan tugas-tugas belajarnya (Nurul Rahmi, dalam Jurnal Administrasi Pendidikan. Volume 2 Nomor 1, Juni 2014. HIm. 532).

Tujuan pembinaan peserta didik adalah meningkatkan peran serta dan inisiatifnya untuk menjaga dan membina sekolah sebagai wiyatamandala, sehingga terhindar dari usaha pengaruh yang bertentangan dengan kebudayaan nasional, menumbuhkan daya tangkal terhadap pengaruh negatif yang datang dari luar lingkungan sekolah; memantapkan kegiatan kokurikuler dan ekstrakulikuler dalam menunjang pencapaian kurikulum; meningkatkan apresiasi dan penghayatan seni; menumbuhkan sikap berbangsa dan bernegara; meneruskan dan meningkatkan kesegaran jasmani dan rohani serta rekreasi; dalam wadah Organisasi Siswa Intra Sekolah/ OSIS (Gilang, Jurnal Inprovement, Edisi 3.2015).

Lembaga pendidikan (sekolah) dalam pembinaan peserta didik biasanya melakukan kegiatan tersebut dengan kegiatan kurikuler dan kegiatan esktra kurikuler. Kegiatan kurikuler adalah semua kegiatan yang telah ditentukan di dalam kurikulum yang pelaksanaanya dilakukan pada jam-jam pelajaran. Kegiatan kurikuler dalam bentuk proses belajar mengajar di kelas dengan nama mata pelajaran atau bidang studi yang ada di sekolah. Sedangkan kegiatan esktrakurikuler merupakan kegiatan peserta didik yang dilaksanakan diluar 
ketentuan yang telah ada dalam kurikulum. Kegiatan ekstrakurikuler biasanya terbentuk berdasarkan bakat dan minat yang dimiliki oleh peserta didik (Tim Dosen UPI, 2017:211-212).

Tujuan pendidikan tidak hanya mengembangkan pengetahuan anak, tetapi juga sikap kepribadian, serta aspek emosional, di samping keterampilanketerampilan lain. Kegiatan ekstrakurikuler bertujuan mengembangkan dan mengaplikasikan minat dan bakat peserta didik, memperluas pengetahuan peserta didik, mengenal hubungan antara berbagai pelajaran dan melengkapi pembinaan manusia seutuhnya (Auwzid dan Karwanto, Jurnal Inspirasi Manajemen Pendidikan, Vol. 4 No. 4, April 2014, hlm. 80).

Menurut Suwardi dan Daryanto (2017:115) evaluasi hasil belajar peserta didik berarti kegiatan menilai proses dan hasil belajar peserta didik baik yang berupa kegiatan kurikuler, ko-kurikuler, maupun ekstrakurikuler. Penilian hasil belajar bertujuan untuk melihat kemajuan belajar peserta didik dalam hal menguasai materi pengajaran yang telah dipelajarinya sesuai dengan tujuantujuan yang telah ditetapkan.

Tujuan umum evaluasi peserta didik adalah sebagai berikut (Badrudin, 2014: 61-62), (a) mengumpulkan data-data yang membuktikan taraf kemajuan peserta didik dalam mencapai tujuan yang diharapkan, dan (b) memungkinkan pendidik/guru menilai aktivitas/pegalaman yang didapat.

Ditinjau dari segi kegunaan untuk mengukur keberhasilan peserta didik, ada tiga jenis tes, yaitu: (a) tes diagnostik, adalah tes yang digunakan untuk mengetaui kelemahan-kelemahan peserta didik sehingga berdasarkan kelemahan tersebut dpaat dilakukan pemberian perlakuan yang tepat. (b) tes formatif, dimaksudkan untuk mengetahui sejauh mana peserta didik telah dibentuk setelah mengikuti suatu program tertentu. (c) tes sumatif, dilaksanakan setelah berakhir pemberian sekelompok program atau pokok bahasan (Suwardi dan Daryanto, 2017:117).

Secara garis besar mutasi peserta didik diartikan sebagai proses perpindahan peserta didik dari sekolah satu ke sekolah yang lain atau perpindahan peserta didik yang berada di dalam sekolah (Badrudin, 2014: 69). Adapun pengertian mutasi menurut Eka Prihatin (2014:142) adalah perpindahan peserta didik dari kelas satu ke kelas lain yang sejajar, dan atau perpindahan peserta didik dari sekolah satu ke sekolah lain yang sejajar. Mutasi ini dapat dilakukan oleh peserta didik, oleh karena ia memang berhak untuk mendapatkan layanan pendidikan sesuai dengan yang ia butuhkan dan ia minati. Persyaratan-persyaratan yang ditentukan, peserta didik tersebut harus diterima. Penetuan persyaratan demikian sangatlah penting, oleh karena kalau tidak, peserta didik akan pindah ke sekolah-sekolah favorit, sementara sekolahsekolah yang tidak favorit akan semakin kehilangan peserta didiknya.

Mutasi ekstern menurut Badrudin (2014 69-70) adalah perpindahan peserta didik adalah dari satu sekolah ke sekolah yang lain. Perpindahan ini 
hendaknya menguntungkan kedua belah pihak, artinya perpindahan tersebut. Adapun tujuan mutasi ekstern adalah mutasi didasarkan pada kepentingan peserta didik untuk dapat mengikuti pendidikan di sekolah sesuai dengan keadaan dan kemampuan peserta didik serta lingkungan yang mempengaruhinya, dan memberikan perlindungan kepada sekolah tertentu untuk dapat tumbuh dan berkembang secara sewajarnya sesuai dengan keadaan, kemampuan sekolah serta lingkungan yang mempengaruhinya.

Mutasi intern menurut Badrudin (2014:71-72) adalah perpindahan peserta didik dalam suatu sekolah. Dalam hal ini akan dibahas khusus mengenai kenaikan kelas. Maksud kenaikan kelas adalah peserta didik yang telah dapat menyelesaikan program pendidikan selama satu tahun, apabila telah memenuhi persyaratan untuk dinaikan, maka kepadanya berhak untuk naik kelas berikutnya.

Madrasah dalam kontek mempersiapkan peserta didik menghadapi zaman di era globalisasi memiliki peran strategis yang amat penting. Keberhasilan madrasah dalam menghadapi tantangan yang sangat komplek, dan diharapkan mampu melahirkan generasi bangsa yang memiliki keunggulan kompetitif dan berperan aktif dalam menentukan arah perkembangan bangsa ini. Kaitannya dengan persaingan di era perubahan saat ini dan masa depan. Madrasah juga diharapkan mampu mempersiapkan peserta didiknya siap bersaing di berbagai bidang. Hal ini penting agar bidang tersebut tidak hanya dikuasai oleh lulusan non-madrasah yang belum tentu memiliki mental keagamaan yang kuat (Yusuf Umar, Jurnal Online. Manajemen Peningkatan Madtasah Bermutu. 2017).

\section{METODE PENELITIAN}

Penelitian ini menggunakan pendekatan kualitatif dengan metode deskriptif kualitatif yaitu metode untuk mendeskripsikan realitas yang ada di lokasi penelitian. Teknik pengumpulan data terdiri dari tiga cara yaitu melalui teknik observasi, wawancara dan studi dokumentasi. Observasi dilakukan melalui pengamatan baik secara langsung maupun tidak langsung dengan menggunakan seluruh pancaindera.Peneliti melakukan wawancara melalui percakapan tanyajawab untuk memperoleh informasi dari narasumber. Studi dokumentasi dilakukan untuk mengumpulkan dokumen dan data-data pendukung terkait dengan penelitian. Teknik analisis data penelitian dimulai dari proses analisis sebelum ke lapangan, analisis data di lapangan (reduksi data, penyajian data, dan penarikan kesimpulan), dan analisis data selama di lapangan. Sedangkan teknik keabsahan data terdiri dari perpanjangan pengamatan, meningkatkan ketekunan, triangulasi, analisis kasus negatif, menggunakan bahan referensi, keikutsertaan, dan mengadakan member check. Proses ini dilakukan untuk membuktikan bahwa data yang diterima merupakan data yang sebenarnya terdapat pada tempat penelitian. 


\section{HASIL DAN PEMBAHASAN \\ Perencanaan Peserta Didik}

Di Madrasah Tsanawiyah Al-Mursyid Kota Bandung dalam setiap tahunnya mengenai jumlah ruangan dan sarana prasarana yang di butuhkan dari pihak sekolah harus sesuai dengan rasio yang telah di tetapkan oleh Peraturan Pemerintah dengan perbandingan 20-1 siswa perguru/ per wali kelas.

Pelaksanaan rekrutmen peserta didik meliputi: (1) Pembentukan panitia penerimaan peserta didik baru melibatkan guru, pengurus OSIS dan peserta didik dan panitia ini di bentuk dalam jangka waktu 3 bulan sebelun tahun ajaran baru di mulai, dan (2) Pembuatan dan penyebaran informasi peserta didik baru di mulai kepada SD-SD terdekat dengan sekolah/Madrasah Tsanawiyah AlMursyid serta kerjasama dengan panti asuhan yang di dukung oleh kartu KIP (Kartu Indonesia Pintar) dan bahkan ada yang daftar sendiri ke sekolah/ Madrasah Tsanawiyah Al-Mursyid.

Proses seleksi peserta didik yang dilakukan di Madrasah Tsanawiyah AlMursyid Kota Bandung adalah melalui beberapa tahap yang dilakukan dalam proses seleksi peserta didik yaitu (1) Proses administrasi, (2) Tes, dan (3) Orientasi Peserta Didik.

Orientasi yang dilakukan di Madrasah Tsanawiyah Al-Mursyid kota bandung adalah melakukan program MPLS atau Masa Pengenalan Lingkungan Sekolah yang di lakukan pihak sekolah selama kurang lebih 3 hari, kegiatan ini di mulai dari sosialisasi tentang kelembagaaan hingga ke tata tertib yang ada di Madrasah Tsanawiyah Al-Mursyid Kota Bandung, selain itu pada masa kegiatan MPLS ini juga pihak sekolah mengikut sertakan kepala sekolah hingga guru-guru untuk memperkenalkan apa saja yang ada di Madrasah Tsanawiyah Al-Mursyid.

Dalam penempatan peserta didik ini, pihak Madrasah Tsanawiyah AlMursyid Kota Bandung ini tidak ada dikarenakan kapasitas siswanya yang tidak terlalu banyak jadi tidak adanya berbedaan antara peserta didik satu dengan yang lainnya.

Untuk pencatatan di Madrasah Tsanawiyah Al-Mursyid Kota Bandung yaitu dari mulai peserta didik masuk sekolah sampai ia keluar dari sekolah. Adapaun pencatatan yang di lakukan oleh Madrasah Tsanawiyah Al-Mursyid Kota Bandung ini, yaitu setiap wali kelas mempunyai catatan masing-masing peserta didik, dari peserta didik masuk hingga peserta didik yang sholat ataupun tidaknya, selain itu juga catatan yang di lakukan ini adalah mencatat setiap prilaku anak-anak, selain kegiatan itu, daftar hadir peserta didik pun penting dalam proses pencatatan.

\section{Pembinaan Peserta Didik}

Kegiatan ekstrakurikuler yang ada di Madrasah Tsanawiyah Al-Mursyid Kota Bandung terbagi kedalam 3 jenis kegiatan ekstrakurikuler yaitu kegiatan 
OSIS, PRAMUKA, dan PADUS (paduan suara), dikarenakan jumla anak yang tidak cukup banyak jadi setiap kegiatan ekstrakulikuler ini bersifat wajib untuk memberikan dan mengembangkan minat dan bakat peserta didik selain dalam bidang akademik. Oleh karenakan itu kegiatan ini dapat membentuk peserta didik dalam mengelola waktu antara belajar di kelas dan belajar di luar kelas seperti mengikuti kegiatan ekstrakulikuler.

Kegiatan ektrakurikuler OSIS yang di bina oleh kesiswaan merupakan suatu organisasi kesiswaan yang berada di lingkungan sekolah. Tujuan didirikannya OSIS adalah untuk melatih siswa MTs Al-Mursyid dalam berorganisasi dengan baik dan menjalankan kegiatan sekolah yang berhubungan dengan siswa juga erat hubungannya dengan membantu untuk mewujudkan program sekolah. Sebagai wadah organisasi siswa di sekolah untuk mencapai tujuan pembinaan dan pengembangan kesiswaan yang selaras dengan visi dan misi sekolah maka organisasi ini bersifat intra sekolah, artinya tidak ada hubungan organisatoris dengan OSIS di sekolah lain, dan tidak menjadi bagian dari organisasi lain yang ada di luar sekolah. Karena OSIS sendiri merupakan wadah organisasi siswa di sekolah, maka setiap siswa MTs Al-Mursyid secara otomatis menjadi anggota OSIS. Keanggotaan itu secara otomatis berakhir dengan keluarnya siswa dari sekolah yang bersangkutan.

Selanjutnya kegiatan esktrakuriluler di Madrasah Tsanawiyah Al-Mursyid Kota Bandung ini adalah kegiatan PRAMUKA, kegiatan pramuka ini sangat sering dilakukan di sekolah, seperti kegiatan yang dilaksanakan di luar sekolah maupun kegiatan yang dilakukan di dalam sekolah. Kegiatan Pramuka ini sering melakukan kegiatan di luar seperti yang dilakukan beberapa hari kemarin kegiatan pramuka yang dilaksanakan pihak sekolah adalah camping di gunung batu. Untuk jadwal kegiatan pramuka ini adalah setiap hari kamis jam 09.0011.00 WIB.

Sedangkan untuk kegiatan PADUS (Paduan Suara) yang di pimpin oleh kesiswaan dan di ajaran oleh guru-guru yang ahli dalam seni dan vocal, ini merupakan kegiatan yang ada di sekolah yang berupa wajib dikarenakan dalam setiap acara upacara atau apapun para anggota PADUS di suruh untuk tampil

Kegiatan kurikuler ini lebih kepada kegiatan akademik yang dimana didalamnya ada kegiatan keagamaan juga, contohnya seperti pembiasaan yang di lakukan sebelum anak-anak mulai belajar, kegiatan pembiasaan ini adalah kegiatan membaca asmaul husna yang di lakukan setiap kelasnya. Dalam kegiatan kurikuler ini melatih anak-anak untuk mengahafal juz 30 atau juz ama. Dan bagi anak-anak yang ingin belajar imla atau menulis arab pun ada gurunya.

\section{Evaluasi Peserta Didik}

Evaluasi dilakukan supaya guru bisa mengetahui sejauh mana peserta didik bisa menerima dan memahami apa yang telah di ajarkan atau diberikan oleh guru kepada peserta didik, kemudian untuk mengukur dan mengetahui 
keberhasilan peserta didik melalui tes dioagnostik, tes formatif, dan tes sumatif agar siswa menjadi lebih baik. Ketika dalam hasil evaluasi pencapaian dan penyampaian materi kepada peserta didik oleh guru tidaklah optimal dikarenakan kurangnya jam pelajaran yang sesuai dengan yang telah ditentukan, itu semua dikarenakan oleh faktor banyaknya hari libur ujian kelas IX yang terjadi dalam dalam waktu tiga minggu yang terdiri dari satu minggu UAMBN (Ujian Akhir Madrasah Berbasis Nasional) yang terdiri dari mata pelajaran agama seperti aqilah akhlak; al-quran hadits; bahasa arab; fiqih; dan sejarah kebudayaan islam. Satu minggu UNBK (Ujian Nasional Berbasis Komputer) yang terdiri dari bahasa Indonesia, matematika, bahasa inggris, dan tiga mata pelajaran sesuai jurusan seperti sosiologi, geografi, dan ekonomi. Dan yang satu minggu UASBN (Ujian Akhir Sekolah Berbasis Nasional) yang terdiri dari mata pelajaran umum yang tidak di UNBK.

Evaluasi yang dilakukan melalui tes ini adalah dengan mengetahui kelemahan-kelemahan peserta didik sehingga dalam mengetahui kelemahannya para guru bisa mengetahui letak kesulitan belajar para peserta didik dalam memahami mata pelajaran.

Evaluasi yang dilakukan melalui tes ini adalah dengan mengetahui sejauh mana peserta didik telah terbentuk setelah mengikuti semua program pembelajaran yang telah di berikan oeh guru kepada peserta didik.

Dalam tes ini para guru melakukannya dengan cara memberikan UH (Ulangan Harian), UTS (Ujian Tengan Semester), dan UAS (Ujian Akhir Semester), serta remedial bagi peserta didik yang kurang dari KKM (Kriteria Kelulusan Minimal) yang dilakukan selama proses kegiatan belajara mengajar berlangsung

\section{Mutasi Peserta Didik}

Pelaksanaan mutasi intern yaitu bisa dikatakan juga dengan kenaikan kelas, kenaikan kelas dilaksanakan pada akhir tahun pelajaran setelah para siswa melaksanakan evaluasi hasil belajar. Setiap kenaikan kelas peserta didik harus memenuhi beberapa persyaratan salah satunya adalah masalah kehadiran.

Mutasi ekstern di Madrasah Tsanawiyah Al-Mursyid Kota Bandung ini belum pernah ada siswa yang di dikeluarkan karena masalah besar seperti berkelahi atau meminum minuman keras atau yang bersangkutan dengan pihak berwajib, sejauh ini tidak ada peserta didik yang mutasi ekstern dikarenkan sebelumnya sudah membuat perjanjian antara pihak sekolah dengan pihak orang tua supaya anaknya tidak melanggar tata tertib yang ada di sekolah. tetapi banyaknya peserta didik yang masuk ke sekolah karena beberapa hal.

Hal yang di lakukan Madrasah Tsanawiyah Al-Mursyid dalam menganggulangi peserta didik yang mutasi adalah dengan adanya perjanjian antara pihak sekolah dan pihak orang tua yang mendaftarkan anaknya ke Madrasaha Tsanawiyah Al-Mursyid Kota Bandung. Dan memberikan arahan tentang tata tertib yang ada di sekolah supaya anak-anak bisa mematuhinya, dan bagi mutasi intern lebih kepada kenaikan kelas yang memberikan syarat 
kenaikan kelas adalah adanya syarat kehadiran yang $70 \%$ anak untuk bisa melaksanakan ulangan akhir semeseter.

\section{Faktor Penunjang dan Penghambat Manajemen Peserta Didik}

Dalam kegiatan manajemen peserta didik yang ada di sekolah tentunya pasti ada faktor penunjang dan penghambatnya, untuk itu faktor penunjang yang ada di sekolah adalah sebagai berikut: (1) Semua tenaga pendidik dan kependidikan ikut kerja sama untuk mencapai tujuan yang jelas. (2) Adanya kerjasama antara guru dengan orang tua peserta didik supaya peserta didik menjadi lebih baik lagi. (3) Semua kegiatan terprogram dengan jelas dari mulai perencanaan hingga hasil evaluasi.

Faktor penghambat manajemen peserta didik diantaranya sebagai berikut: (1) Rendahnya sarana prasarana yang menunjang proses pembelajaran peserta didik, yang harusnya setiap mata pelajaran mempunyai alat peraga untuk menjelaskan kepada peserta didik. (2) Rendahnya kualitas guru ini diakibatkan keterlambatannya pencairan serfikasi guru sehingga guruguru tidak semangat untuk mengajar. (3) Tingkat ekonomi peserta didik yang kurang memadai sehingga pihak sekolah tidak bisa memberikan fasilitas lebih kepada peserta didik.

\section{Hasil Manajemen Peserta Didik}

Hasil yang dicapai dari manajemen peserta didik adalah semua kegiatan bisa tersusun dengan baik terutama mengenai peserta didik dari peserta didik masuk hingga peserta didik keluar atau menjadi alumni sekolah. Selain itu juga dari hasil manajemen peserta didik ini pihak sekolah mendapatkan keuntungan dari dua prestasi yaitu prestasi akademik dan prestasi non akademik, untuk prestasi akademik pihak sekolah pernah mendapatkan predikat tingkat Kota yaitu perlombaan IPA dan untuk mengenai keagamaanya pihak sekolah menjuari perlombataan keagamaan. Tidak kalah menarik untuk prestasi non akademik sangatlah memuaskan para peserta didik bisa menjuarai berbagai bidang salah satunya yaitu pramuka pada tingkat kecamatan, renang pada tingkat Kota, futsal, dan ikut paduan suara di pendopo kota bandung.

\section{REFERENSI}

Auwzid dan Karwanto. Jurnal Inspirasi Manajemen Pendidikan, tentang Manajemen Peserta Didik Di Smp Baitussalam Surabaya, Vol. 4 No. 4, April 2014.

Badrudin, (2013). Dasar-Dasar Manajemen, Bandung: Alfabeta.

Badrudin, (2014). Manajemen Peserta Didik, Jakarta Barat: Indeks.

Dini Oktaria, Jurnal Administrasi Pendidikan. Persepsi Siswa Tentang Manajemen Peserta Didik di SMK Tri Dhrama Kosgoro 2 Padang. Volume 2 Nomor 1, Juni 2014.

Eka Prihatin. (2014). Manajemen Peserta Didik, Bandung: Alfabeta.

Gathut Oktriwan Sumarsono dan Desi Nurhikmahyanti. Jurnal Inspirasi Manajemen Pendidikan. Pelaksanaan Manajemen Peserta Didik Sebagai 
Pem bentukan Karakter Siswa Di SMA Negeri 1 Pilangkenceng Kabupaten Madiun, Vol. 4 No. 4, April 2014.

Gilang Cahyo N. T, Jurnal Inprovement, Manajemen Pembinaan Peserta Didik Pada Sekolah Penyelenggara Pendidikan Inklusi Smp Negeri 232 Jakarta, Edisi 3, 2015.

https://jurnalimprovement.wordpress.com/2016/07/13/pembinaan-pesertadidik/ di akses pada tanggal 12 Februari 2018 pukul 21.00 WIB

Jaja Jahari dan Amirulloh Syarbini. (2013). Manajemen Madrasah, Bandung: Alfabeta.

Nurul Rahmi, Jurnal Administrasi Pendidikan. Persepsi Guru Tentang Manajemen Peserta Didik Sekolah Dasar Negeri Gugus li Kecamatan Lubuk Sikarah Kota Solok, Volume 2 Nomor 1, Juni 2014.

Suwardi dan Daryanto. (2017). Manajemen Peserta Didik, Yogjakarta: Gava Media.

Tim Dosen UPI. (2017). Manajemen Pendidikan, Bandung: Alfabeta. 